\title{
Association of indoor microbial aerosols with respiratory symptoms among under-five children: a systematic review and meta-analysis
}

\author{
Adekunle Gregory Fakunle ${ }^{1,2^{*}} \mathbb{0}$, Nkosana Jafta ${ }^{1}$, Rajen N. Naidoo ${ }^{1}$ and Lidwien A. M. Smit ${ }^{3}$
}

\begin{abstract}
Background: Despite the recognition of the importance of indoor microbial exposures on children's health, the role of different microbial agents in development and aggravation of respiratory symptoms and diseases is only poorly understood. This study aimed to assess whether exposure to microbial aerosols within the indoor environment are associated with respiratory symptoms among children under- 5 years of age.

Methods: A systematic literature search was conducted on PubMed, Web of Science, GreenFILE, ScienceDirect, EMBASE and Cochrane library through February 2020. Studies that investigated the exposure-response relationship between components of the indoor microbial communities and respiratory symptoms among under-five children were eligible for inclusion. A random-effect meta-analysis was applied to estimate pooled relative risk (RR) and 95\% confidence interval (Cl) for study specific high versus low microbial exposures. The potential effect of individual studies on the overall estimate was evaluated using leave-one-out analysis, while heterogeneity was evaluated by $P^{2}$ statistics using RevMan 5.3.

Results: Fifteen studies were eligible for inclusion in a meta-analysis. The pooled risk estimate suggested that increased microbial exposure was associated with an increased risk of respiratory symptoms [pooled relative risk (RR): $1.24(1.09,1.41), P=0.001]$. The association was strongest with exposure to a combination of Aspergillus, Penicillium, Cladosporium and Alternaria species [pooled RR: $1.73(1.30,2.31), P=0.0002]$. Stratified analysis revealed an increased risk of wheeze [pooled RR: $1.20(1.05,1.37), P=0.007$ and allergic rhinitis [RR: $1.18(0.94,1.98), P=0.16$ ] from any microbial exposure.
\end{abstract}

Conclusions: Microbial exposures are, in general, associated with risk of respiratory symptoms. Future studies are needed to study the indoor microbiome more comprehensively, and to investigate the mechanism of these associations.

Keywords: Indoor microbiome, Respiratory symptoms, Asthma, Under-five children, Meta-analysis

\section{Background}

The microbial community within indoor environments such as dwellings where humans, especially under-five children, spend more than $90 \%$ of their time, consists of a wide range of microorganisms including bacteria, fungi,

\footnotetext{
*Correspondence: fakunz@yahoo.com

2 Department of Medicine, University of Ibadan, Ibadan 200284, Nigeria

Full list of author information is available at the end of the article
}

and viruses [1-4]. The microbial load and composition within the indoor environment is determined and influenced by the presence, identity and activities of human occupants [5-7]. Non-human occupants, such as dogs $[8,9]$ and household insects [10], can also influence the microbial profile of the indoor environment. In addition, indoor microbial communities can be influenced by differences in ventilation, building design, the environmental characteristics found within buildings $[9,11$, original author(s) and the source, provide a link to the Creative Commons licence, and indicate if changes were made. The images or other third party material in this article are included in the article's Creative Commons licence, unless indicated otherwise in a credit line to the material. If material is not included in the article's Creative Commons licence and your intended use is not permitted by statutory regulation or exceeds the permitted use, you will need to obtain permission directly from the copyright holder. To view a copy of this licence, visit http://creativecommons.org/licenses/by/4.0/. The Creative Commons Public Domain Dedication waiver (http://creativeco mmons.org/publicdomain/zero/1.0/) applies to the data made available in this article, unless otherwise stated in a credit line to the data. 
12] or prior water damage [13]. The interest in the indoor microbiome has increased over the last few decades [1]. This is largely because of the wider recognition that exposures to microbes in the residential indoor environment are associated with a vast number of adverse health outcomes with major public health importance, including infectious diseases, acute toxic effects, allergies and cancer [1].

Most epidemiological studies have been heterogeneous in assessing different respiratory health effects associated with exposure to specific microbial components, especially endotoxins, and culturable molds [14-17] while very few have investigated indoor microbial communities $[18,19]$. These studies have shown inconsistent findings, suggesting protective, detrimental, and no health effects in relation to asthma and allergy [14]. Greater diversity of fungal and bacterial agents has been shown to reduce the risk of asthma and wheeze in children [17, 20, 21] while others found a positive association between elevated levels of total viable mold and risk of rhinitis with persistent cough [22-24].

Respiratory health effects have been the subject of recent research among preschool children $[25,26]$ and children under the age of 5 years [27]. Children under the age of 5 years are more at risk of respiratory outcomes from exposure to indoor microbial agents due to the fact that they spend a considerable proportion of time in the home environment during a period of intense growth and development of the immunologic and respiratory systems $[28,29]$. Despite the recognition of the importance of exposure to the indoor microbiome on children's health, the precise role of different microbial agents in the development and aggravation of symptoms and diseases is only poorly understood. It is therefore not clear which specific component(s) primarily contribute to the presumed respiratory health effects. To the best of our knowledge, there has been no systematic review or meta-analysis exploring the role of the indoor microbial exposure on respiratory health outcomes among children under 5 . Therefore, this systematic review and meta-analysis aims to summarize evidence of associations between different indoor microbial agents and their combined role in the incidence of respiratory allergies and asthma, thereby providing opportunities to improve future respiratory health interventions among under-five children.

\section{Methods and design}

Literature search

The protocol for this meta-analysis was reported using MOOSE guideline [30] and registered in the International Prospective Register of Systematic Reviews (Reg ID: CRD42020178514). Two reviewers independently explored PUBMED, WEB OF SCIENCE, GREEN FILE
(EBSCO), ScienceDirect, EMBASE and Cochrane databases independent of date through February 2020 to identify appropriate previously published studies using the following search terms; "home" OR "house" OR "dwelling" OR "residence" OR "residential" OR "indoor" OR "domicile" OR "living unit" OR "property" OR "build" OR "built environment" OR "domestic environment" OR "bedroom" OR "living room" OR "wall" OR "floor" OR "ceiling" OR "construction material" AND "damp" OR "fungi" OR "mold" OR "mould" OR "fungal" OR "fungus" OR "bacteria" OR "virus" OR "microbial" OR "microbiome" OR "microbial diversity" OR "microbial load" OR "microbial burden" OR "microbiota" OR "biodiversity" AND "respiratory symptoms" OR "allergy" OR "hay fever" OR "cough" OR "fever" OR "difficulty breathing" OR "wheeze" OR "allergic rhinitis" OR "sinusitis" OR "asthma". Title and abstract of each article was evaluated independently and differences on which publication(s) to include were clarified by recourse to a third reviewer. A snowball search was also carried out by screening reference lists of publications and reviews.

\section{Inclusion criteria and study selection}

Studies eligible for inclusion in the meta-analysis were epidemiological reports in humans with exposureresponse relationship between indoor microbial aerosols and respiratory symptoms. Inclusion criteria were: (I) qualitative or quantitative assessment of indoor microbial aerosols. Studies that reported exposure to specific microbial communities (bacteria, fungi, viruses, and/or microbial by-products) or presence/absence of visible molds were included; (II) studies conducted among children aged $\leq 5$ years; (III) respiratory symptoms (including wheeze/allergic rhinitis) and/or asthma adequately defined and described; (IV) full text articles in English originally published in peer reviewed journals. Literature reviews, abstracts, letters to the editor, case reports, and non-human studies were excluded.

Assessment of articles was performed in EndNote databases. All duplicates were removed and studies were selected based on title or abstract for full text-screening. For studies that were excluded, the reasons for exclusion were listed.

\section{Data extraction}

From the studies that met the inclusion criteria, the following information was extracted: (1) name and initials of the first author, (2) year of publication, (3) country, (4) type of sample, (5) sampling equipment, (6) microbial agent(s), (7) analytical method, (8) level and measure of exposure, (9) respiratory outcome definition, (10) number of cases, (11) sample size and (12) effect estimate. All 
incongruities from the data extracted were resolved by a third author.

\section{Quality assessment of included studies}

Two team members (AGF and NJ) assessed the methodological quality and risk of bias of the included studies using the Cochrane Collaboration guidelines [31] and the Newcastle-Ottawa scales [32]. The quality of the studies was graded by rating nine items representing the study selection procedure, comparability, and outcome/ exposure definition. Each item was scored as 'yes' (if present) and 'no' (if absent) in the included studies and the overall scores were presented as percentages. Studies with median a score $\geq 80 \%$ (median in our study) were arbitrarily considered to have a low risk of bias while those with a score $<80 \%$ were considered to have a high risk of bias.

\section{Statistical analyses}

All statistical analysis was carried out using Review Manager 5.3. We applied the inverse of variance method for weighting and computed the summary effect estimates by first log-transforming all relative risk (RR) and 95\% confidence interval $(\mathrm{CI})$ for high vs low category (as reference) of microbial exposure. The standard error (SE) was estimated based on the formula:

$$
\mathrm{SE}=[\log (\text { upper limit of the } 95 \% \mathrm{CI})-\log (\text { lower limit of the 95\% CI)/3.92] }
$$

The extent of variability across studies and heterogeneity of the summary effect estimates were evaluated using $I^{2}$ test statistics. Where $I^{2}$ statistics $\geq 50 \%$, a random effect model was employed, otherwise, a fixed effect model [30, 33]. The area of the black square in forest plots implies the weighted contribution by each study. Sensitivity analyses of the results and publication bias was evaluated using leave-one-out and funnel plot techniques respectively. $P<0.05$ (two-tailed) was considered statistically significant [34].

\section{Results}

The PRISMA flowchart describing the process used to identify the studies eligible for our meta-analyses yielded 3,107 records (Fig. 1). In addition, duplicates $(n=598)$ and other records $(n=2,345)$ after screening titles and abstracts were excluded, resulting in 164 articles for full text assessment. In total, fifteen articles that fulfilled all inclusion criteria were included in the metaanalyses [23, 35-48].

Detailed characteristics of the included studies are presented in Tables 1 and 2. All fifteen studies had a cohort design with follow-up period between 1 [35, 37-39, 41, $42,48]$ and $4[40,47]$ years. Eleven studies were carried out in the United States and four in Europe all between 2000 and 2019. All studies included examined indoor microbial exposure among children under the age of 5 years. The methods of assessment of exposure to indoor microbial aerosols used among studies included air sampling [35, 39], dust sampling [37, 38, 40-44, 46-48] and home inspection using a standard observational checklist [45]. In addition, two studies [23, 36] applied a combination of air and dust sampling techniques. The indoor air samples were collected using Burkard portable air sampler [35] and Hirst-type sampler [39] respectively. The dust samples were collected using high volume vacuum cleaners such as Eureka Mighty-Mite vacuum cleaner, Filter Queen Majestic vacuum cleaner and Rowenta Dymbo vacuum cleaner. Microbial agents assessed were total bacteria [36], total fungi [23, 36, 39], specific fungal genera such as Aspergillus spp. [23, 36, 39], Penicillium spp. [23, 35, 36, 39], Cladosporium spp. [23, 35, 36, 39], Alternaria spp. [23, 36], yeast [23, 36, 49], visible molds [23, $45]$ and endotoxins [37, 38, 40-44, 46-48]. In terms of the analytical methods employed, the bacterial and fungal agents were assessed using conventional plate count methods [23, 35, 36] while endotoxins were analysed using the kinetic chromogenic Limulus amebocyte lysate (LAL) test [41-44, 46-48]. Respiratory outcomes in the included studies were allergic rhinitis [23, 42, 43, 45], wheeze [35-44, 46-48] and asthma [44, 47]. These outcomes were assessed by doctors' diagnosis using clinical examination [23, 39, 47] and parental/caregiver's recall [35-38, 40-46, 48]. After a detailed quality assessment of the included studies based on the Newcastle-Ottawa scale for assessing the quality of non-randomized studies, most of the studies $(n=8)$ had a score $<80 \%$ (median in our study) and were categorized as high risk of bias. Others $(n=7)$ were considered to have a low risk of bias (score $\geq 80 \%$ ) (Table S1).

Tables 2 and 3 provided study characteristics and summary effect estimates of all 15 studies [23, 35-48] addressing the association between different indoor microbial exposures and respiratory symptoms among children under 5 . The pooled risk estimate from the random effect model showed a significant association between microbial exposure and respiratory symptoms; RR: $1.24(1.09,1.41), P=0.001, I^{2}=78 \%$ (Fig. 2 A). The risk estimate was observed to vary geographically: RR: 1.35 (1.15, 1.57), $P=0.0001 ; I^{2}=63 \%$ (United States) and RR: $1.06\left(0.87,1.28, P=0.56 ; I^{2}=81 \%\right.$ (Europe). Further stratification showed that the risk estimates were $R R$ : 1.48 (1.25, 1.75), $P<0.00001$ for studies that used air sampling for exposure assessment and RR: $1.12(0.98$, 1.29), $P=0.11$ for studies based on dust sampling techniques. Also, indoor microbial exposure was found to be 


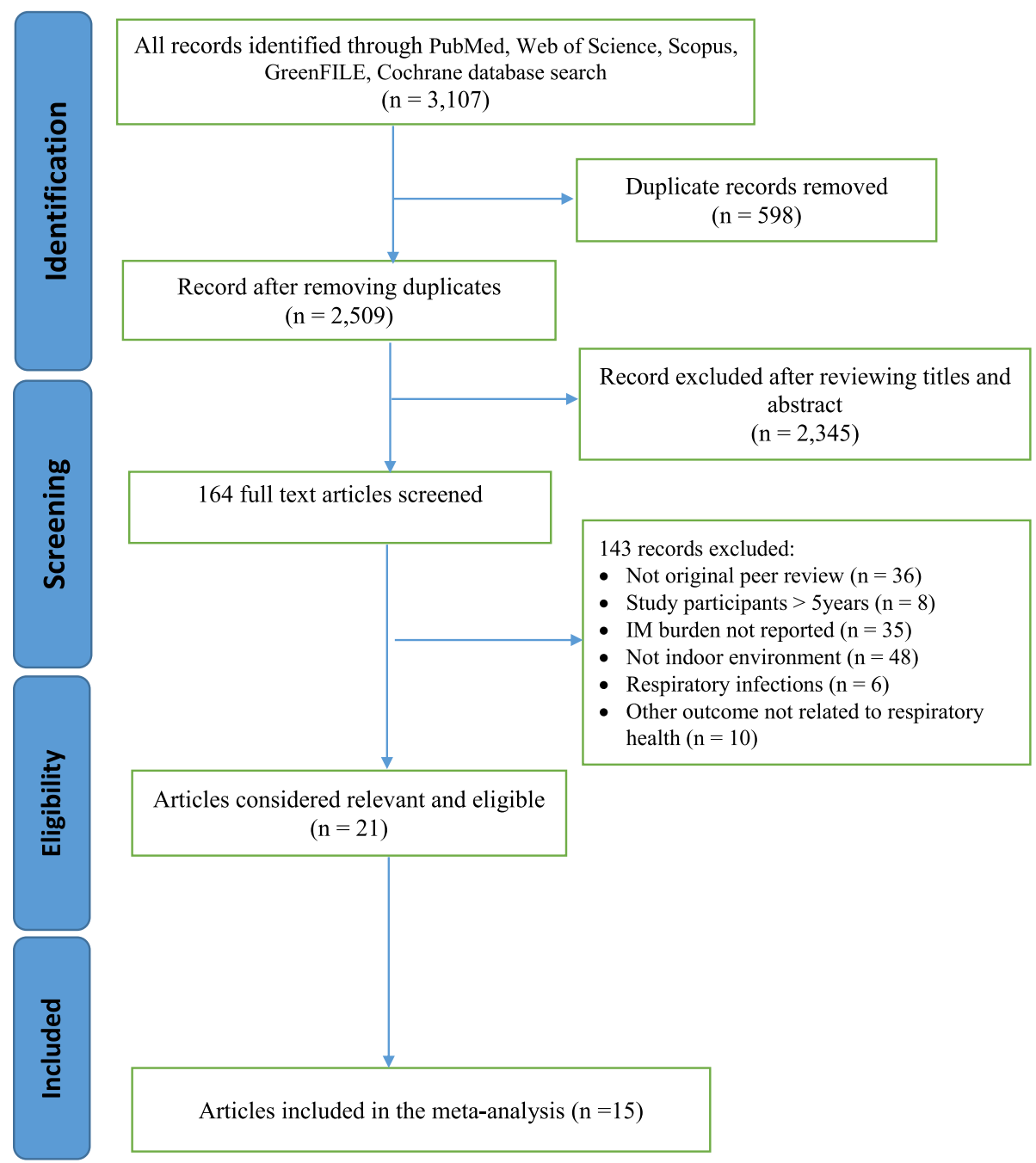

Fig. 1 PRISMA Flow chart of the literature search for studies investigating Exposure to IM and respiratory symptoms among U-5C. IM=Indoor Microbiome; $\mathrm{U}-5 \mathrm{C}=$ Under-five Children

associated with an increased risk of wheeze independent of the risk of bias of studies included in the meta-analysis.

Three studies $[23,36,39]$ provided study-specific estimates for risk of respiratory symptoms from exposure to total fungal concentration; TFC $\left(\mathrm{CFU} / \mathrm{m}^{3}\right)$, resulting in a risk estimate of RR: 1.59 [1.28. 1.97], $P<0.0001$; $I^{2}=0 \%$ (Fig. 2B). Risk of respiratory symptoms based on exposure to specific fungal genera revealed a pooled risk estimate of RR: $1.14[1.06,1.21], P=0.0001$ for Aspergillus species (Fig. 2C), RR: 1.27 [1.05, 1.55], $P=0.01$ for Penicillium species (Fig. 2D), RR: 1.03 [0.88, 1.20], $P=0.71$ for Cladosporium species (Fig. 2E) and RR: 1.31 [0.99, 1.73], $P=0.05$ for Alternaria species (Fig. 2F). The combined model based on four studies [23, 35, 36, 39] showed a significantly increased risk of respiratory symptoms when under-five children were exposed to a combination of two most reported fungal genera; Penicillium spp. and Cladosporium spp. compared to unexposed under-five children [RR: 1.51 (1.31, 1.76), $\left.P<0.00001 ; I^{2}=0 \%\right]$ (model 1). Three studies [23, 36, 39] revealed that exposure to a combination of three commonly reported fungal genera; Aspergillus spp., Penicillium spp. and Cladosporium spp. produced a stronger risk of respiratory symptoms [RR: $1.66(1.34,2.06)$, $\left.P<0.00001 ; I^{2}=0 \%\right]$ (model 2). The study-specific estimates based on two studies $[23,36]$ showed that exposure to a combination of Aspergillus spp., Penicillium spp., Cladosporium spp. and Alternaria spp. significantly increase the risk of respiratory symptoms by 73\% [RR: 1.73 (1.30, 2.31), $P=0.0002 ; I^{2}=0 \%$ ] (model 3) (Table 4). Ten studies [37, 38, 40-44, 46-48] investigated the relationship between endotoxins and respiratory symptoms, 


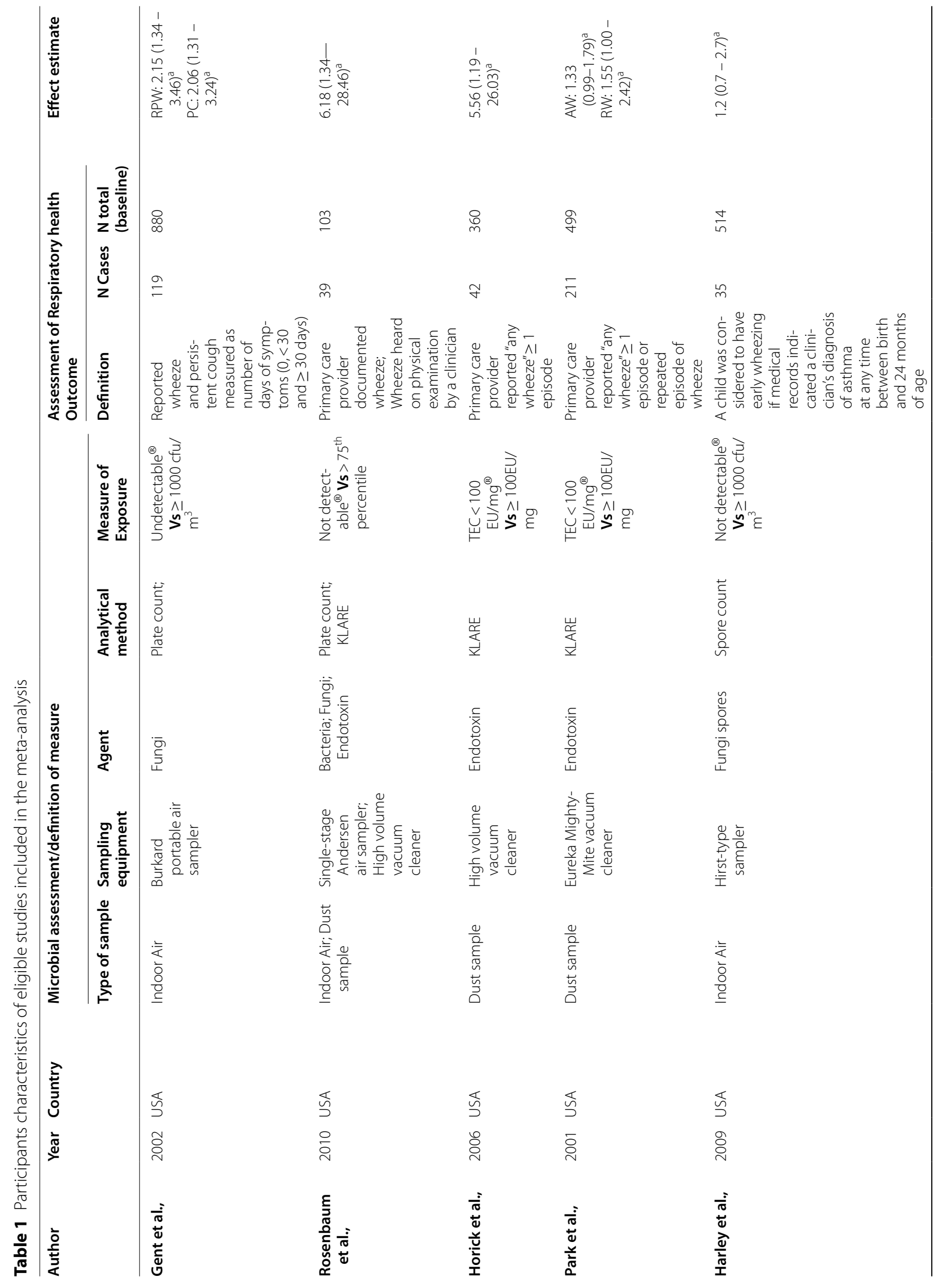




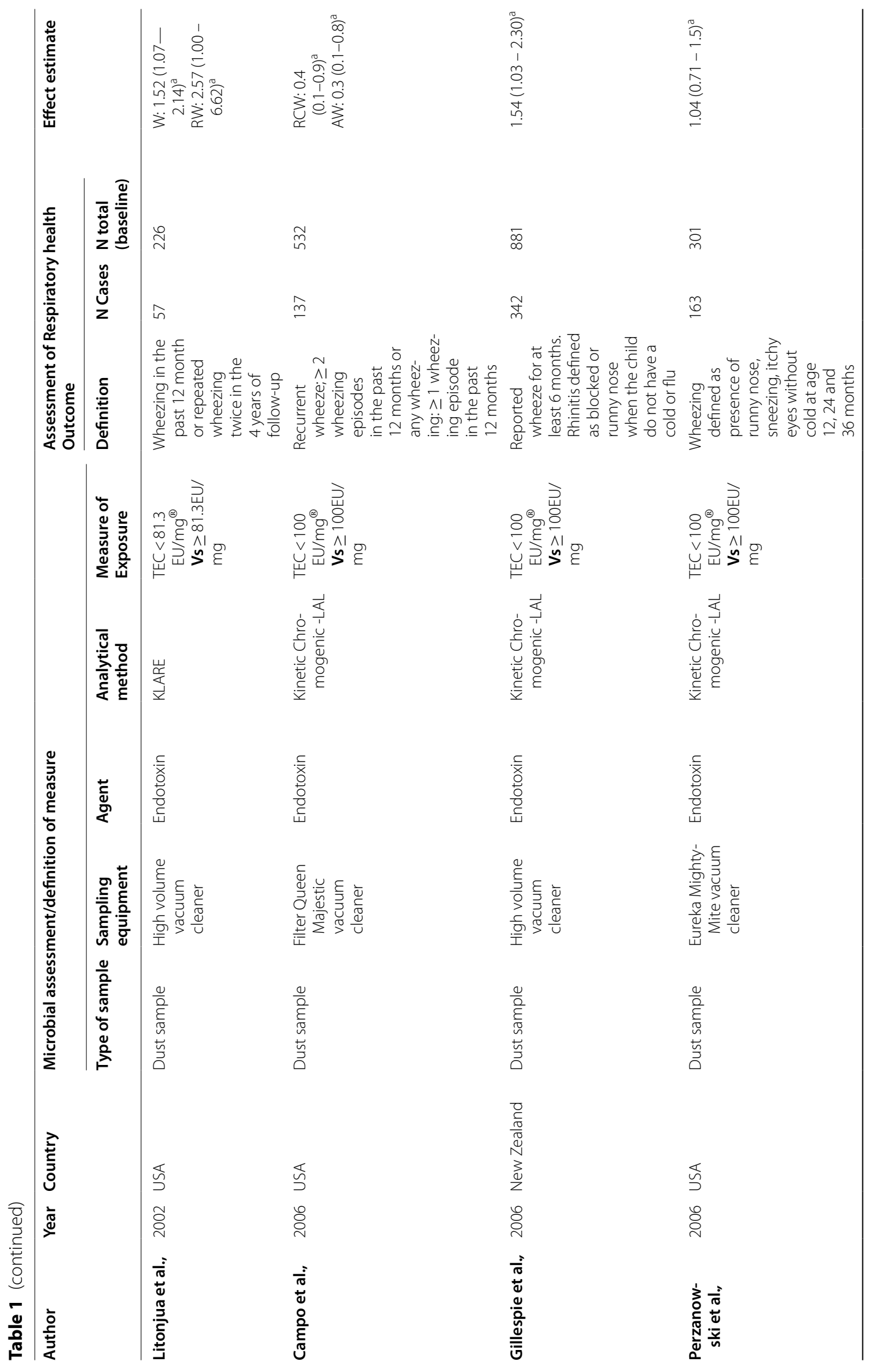




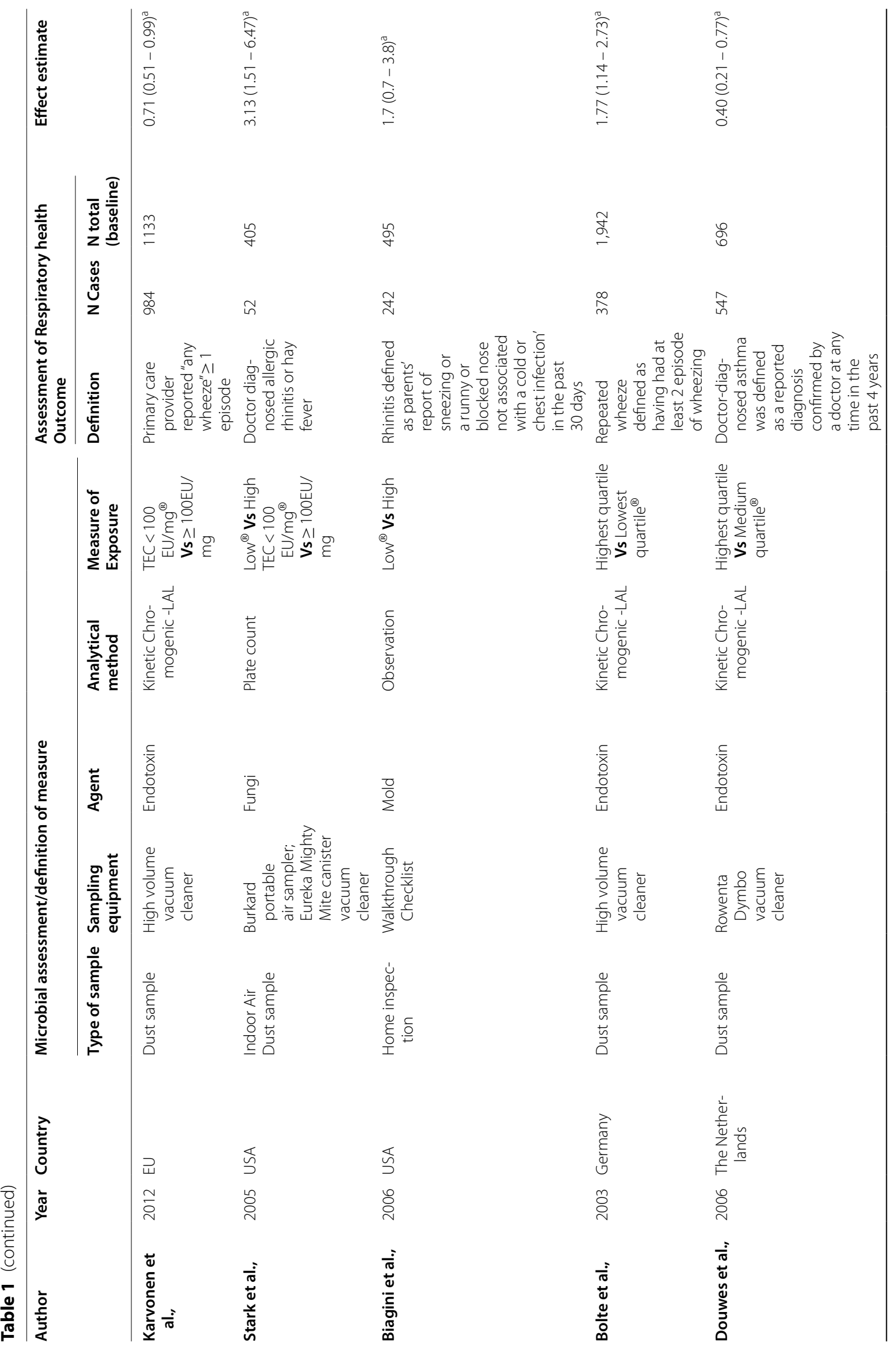




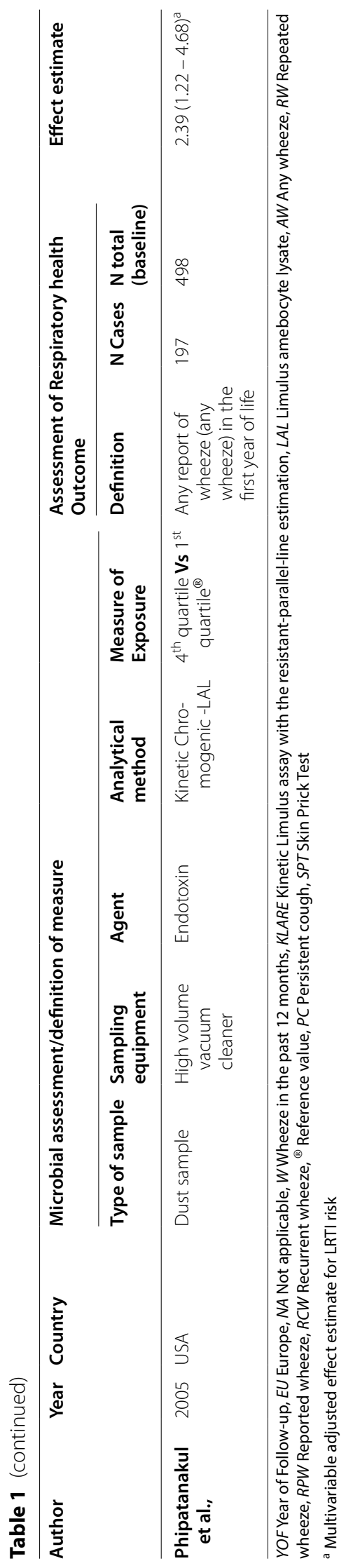


Table 2 Summary effect estimate for the relationship between any IM exposure (highest estimates in the studies) and Respiratory symptoms $(n=15)$, and stratified analysis according to study characteristics

\begin{tabular}{|c|c|c|c|c|}
\hline Stratification & Study Characteristics (Number of studies) & $I^{2}(\%)$ & $\begin{array}{l}\text { Summary Effect Estimate for } \\
\text { pooled adjusted data }[95 \% \mathrm{Cl}]\end{array}$ & $P$-value \\
\hline Population & All studies (15) $[12,18,25-37]$ & 78 & $1.24[1.09,1.41]$ & 0.001 \\
\hline \multirow[t]{2}{*}{ Study size ${ }^{a}$} & Large (6) $[25,30,32,34-36]$ & 82 & $1.14[1.02,1.38]$ & 0.04 \\
\hline & Small (9) $[12,18,26-29,31,33,37]$ & 67 & $1.33[1.11,1.59]$ & 0.002 \\
\hline \multirow[t]{2}{*}{ Geographical Location } & United States (11) $[12,18,25-31,33,37]$ & 63 & $1.35[1.15,1.57]$ & 0.0001 \\
\hline & Europe (4) [32, 34-36] & 81 & $1.06[0.87,1.28]$ & 0.56 \\
\hline \multirow[t]{2}{*}{ Year of Publication } & $2010-2019(2)[12,34]$ & 84 & $1.34[0.58,3.09]$ & 0.49 \\
\hline & $2000-2009(13)[18,25-33,35-37]$ & 60 & $1.25[1.12,1.41]$ & 0.0002 \\
\hline \multirow[t]{3}{*}{ Method of IM Assessment } & Air sampling $(3)[12,25,28]$ & 2 & $1.48[1.25,1.75]$ & 0.0000 \\
\hline & Dust sampling (11) [18, 26, 27, 29, 31-37] & 76 & $1.12[0.98,1.29]$ & 0.11 \\
\hline & Home Inspection (1) [30] & NA & $1.66[0.85,3.21]$ & 0.14 \\
\hline \multirow[t]{2}{*}{ Method of diagnosis } & Doctor diagnosed (2) [18, 28] & NA & $1.60[1.28,2.01]$ & $<0.0001$ \\
\hline & Self-reported (13) [12, 25-27, 29-37] & 76 & $1.19[1.04,1.35]$ & 0.009 \\
\hline \multirow[t]{2}{*}{ Study Quality } & Low risk of bias $(7)[12,18,25,27,28,31,32]$ & 59 & $1.31[1.12,1.55]$ & 0.001 \\
\hline & High risk of bias (8) [26, 29, 30, 33-37] & 75 & $1.17[0.99,1.37]$ & 0.06 \\
\hline
\end{tabular}

NA Not applicable

${ }^{\text {a }}$ A large study was defined as a cohort study with a sample size of greater than 600

resulting in a pooled estimate that was not statistically significant $\left[1.12(0.97,1.28), P=0.12, I^{2}=77 \%\right]$ (Fig. 2G) likewise the relationship between endotoxins and wheeze among under-five children (Fig. 2H) obtained from a pooled risk estimate of nine studies.

Thirteen studies [35-44, 46-48] assessed the association between different microbial exposures and wheeze. The pooled risk estimate from the random effect model showed a significant association between indoor microbial exposure and wheeze [RR: 1.20 (1.05, 1.37), $P=0.007, I^{2}=78 \%$ (Fig. 3). Only four studies [23, $42,43,45]$ investigated the association between different microbial exposure and allergic rhinitis with no significant relationship (Fig. 4). In addition, two studies [44, 47] investigated the association between any exposure and asthma among under-five children with a significant protective effect [RR: $0.78(0.62,0.99), P=0.04]$, (Fig. 5).

The funnel plots showed no significant evidence of publication bias among the studies included in the meta-analyses (Supplementary Figures S1, S2 and S3). We tested the effect of excluding individual studies on the stability of the pooled effect estimates and found no single study exerted significant effect on the overall effect estimate of the meta-analysis. Details of the sensitivity analysis are provided in Supplementary Table S2.

\section{Discussion}

This systematic review and meta-analysis summarizes the current knowledge on the association between qualitative and quantitative estimates of microbial agents within the indoor environment and respiratory symptoms among children under the age of 5 years. To the best of our knowledge, our meta-analysis is the most comprehensive overview to investigate whether exposure to indoor microbial aerosols is associated with respiratory health of children under the age of 5 years. First, we observed that exposure to a combination of Aspergillus, Penicillium and Cladosporium species increased the risk of wheeze by $67 \%$. Secondly, the association of indoor microbial exposure with allergic rhinitis was not significant. Thirdly, exposure to microbial agents such as endotoxins was protective against asthma, although the estimate was from two studies.

The combined analysis revealed an increased risk of wheeze when children under 5 were exposed to a combination of Aspergillus and Penicillium species, which was reduced by the addition of Cladosporium species to the model. This suggests that microbial interaction within the indoor environment may play a role in the respiratory health of children under the age of 5 years. These specific fungi within the indoor environment have also been shown to be associated with an increased risk of wheeze $[17,36]$ and asthma $[24,35,50]$ in longitudinal studies. A similar meta-analysis on fungal exposure and respiratory health in children aged 6-12 years [51] compares well to the pooled estimate reported in our meta-analyses. Relevant studies both in vitro and in vivo have demonstrated that repeated activation of immune responses and inflammation from fungal exposures may contribute to inflammation-related diseases, 
Table 3 Effect estimates (EEs) of studies for the association between IM and respiratory symptoms among U-5C (the highest EEs reported for any IM exposure)

\begin{tabular}{|c|c|c|c|c|c|c|c|c|}
\hline \multirow[t]{2}{*}{$\begin{array}{l}\text { Author, year/ } \\
\text { Country }\end{array}$} & \multicolumn{8}{|c|}{$\begin{array}{l}\text { Type of Exposure and EEs } \\
\text { Adjusted EE }(95 \% \mathrm{Cl})\end{array}$} \\
\hline & Any IM exposure & TFC & Aspergillus spp. & Penicillium spp. & $\begin{array}{l}\text { Cladosporium } \\
\text { spp. }\end{array}$ & Alternaria spp. & Visible molds & Endotoxin \\
\hline $\begin{array}{l}\text { Gent et al., 2002/ } \\
\text { USA [35] }\end{array}$ & $2.15(1.34,3.46)$ & - & - & $2.15(1.34,3.46)$ & $0.91(0.53,1.56)$ & - & & - \\
\hline $\begin{array}{c}\text { Rosenbaum et al., } \\
\text { 2010/USA [36] }\end{array}$ & $6.18(1.34,28.46)$ & $3.64(0.67,19.65)$ & $1.58(0.43,5.79)$ & $6.18(1.34,28.46)$ & $2.28(0.41,12.67)$ & $0.96(0.27,3.45)$ & & - \\
\hline $\begin{array}{l}\text { Horick et al., 2006/ } \\
\text { USA [37] }\end{array}$ & $4.12(1.03,16.83)$ & - & - & - & - & - & & $4.12(1.03,16.83)$ \\
\hline $\begin{array}{l}\text { Park et al., 2001/ } \\
\text { USA [38] }\end{array}$ & $1.56(1.03,2.38)$ & - & - & - & - & - & & $1.56(1.03,2.38)$ \\
\hline $\begin{array}{l}\text { Harley et al., 2009/ } \\
\text { USA [39] }\end{array}$ & $2.80(1.30,5.90)$ & $1.20(0.70,2.00)$ & $1.3(1.10,1.50)$ & $1.3(1.10,1.50)$ & $0.90(0.50,1.60)$ & - & & - \\
\hline $\begin{array}{l}\text { Litonjua et al., } \\
\text { 2002/USA [40] }\end{array}$ & $2.57(1.00,6.62)$ & - & - & - & - & - & & $2.57(1.00,6.62)$ \\
\hline $\begin{array}{l}\text { Campo et al., } \\
\text { 2006/USA [41] }\end{array}$ & $0.40(0.10,0.90)$ & - & - & - & - & - & & $0.40(0.10,0.90)$ \\
\hline $\begin{array}{l}\text { Gillespie et al. } \\
\text { 2006/Europe } \\
\text { [42] }\end{array}$ & $1.54(1.03,2.30)$ & - & - & - & - & - & & $1.54(1.03,2.30)$ \\
\hline $\begin{array}{c}\text { Perzanowski et al. } \\
\text { 2006/USA [43] }\end{array}$ & $1.04(0.71,1.50)$ & - & - & - & - & - & & $1.04(0.71,1.50)$ \\
\hline $\begin{array}{l}\text { Karvonen et al. } \\
\text { 2012/Europe } \\
\text { [44] }\end{array}$ & $0.85(0.72,1.00)$ & - & - & - & - & - & & $0.85(0.72,1.00)$ \\
\hline $\begin{array}{l}\text { Bolte et al., 2003/ } \\
\text { Europe [46] }\end{array}$ & $1.77(1.14,2.73)$ & - & - & - & - & - & & $1.77(1.14,2.73)$ \\
\hline $\begin{array}{l}\text { Douwes et al., } \\
\text { 2006/Europe } \\
\text { [47] }\end{array}$ & $0.40(0.21,0.77)$ & - & - & - & - & - & & $0.40(0.21,0.77)$ \\
\hline $\begin{array}{l}\text { Phipatanakul et al., } \\
\text { 2005/USA [48] }\end{array}$ & $2.39(1.22,4.68)$ & - & - & - & - & - & & $2.39(1.22,4.68)$ \\
\hline $\begin{array}{l}\text { Stark et al., 2005/ } \\
\text { USA [23] }\end{array}$ & $3.13(1.51,6.47)$ & $3.13(1.51,6.47)$ & $2.57(1.22,4.40)$ & $1.51(0.63,3.64)$ & $1.88(0.81,4.35)$ & $2.34(1.12,4.91)$ & $1.66(0.87,3.17)$ & - \\
\hline $\begin{array}{l}\text { Biagini et al., 2006/ } \\
\text { USA [45] }\end{array}$ & $1.70(0.70,3.80)$ & - & - & - & - & - & $1.70(0.70,3.80)$ & - \\
\hline
\end{tabular}

TFC Total Fungal Count

Adjusted model in each study:

- Gent et al., adjusted for socioeconomic factors and housing characteristics

- Rosenbaum et al., adjusted for season of visit, maternal smoking during pregnancy, any smoker in the home, day care center or nonrelative care, and endotoxin - Horick et al., adjusted for race, presence of dog in home, former (not current) dog in home, use of dehumidifier, total mass of dust sample collected (in log scale), presence of concrete floor, missingness indicator for presence of concrete floor, and presence of water damage

- Park et al., adjusted for age, race/ethnicity and socioeconomic characteristics

- Harley et al., adjusted for gas stove in home, respiratory infection in first year of life, and $\mathrm{PM}_{2.5}$ in first 3 months of life (residuals independent of spores)

- Litongua et al., adjusted for maternal asthma, maternal age, sex, prematurity, and area of residence

- Campo et al., adjusted for sex, daycare attendance, number of siblings, mother smokes, parental history of asthma

- Gillespie et al., adjusted for household size, number of rooms in the house, pet in home, dampness, musty smell, maternal smoking, open fireplace, type of flooring in the bedroom, and New Zealand Deprivation index

- Perzanowski et al., adjusted for sex, maternal asthma, ethnicity and tobacco smoke exposure in the home

- Karvonen et al., adjusted for study centre, farming status, gender, maternal history of allergic disease, smoking during pregnancy and number of sibling

- Bolte et al., adjusted for gender, study region, breastfeeding, elder siblings, parental education, mite and cat allergen levels, frequent respiratory infections and smoking during pregnancy

- Douwes et al., adjusted for sex, region, parental education level, exposure to indoor tobacco smoke in the past 4 years, and other children in the household at 4 years of age

- Phipatanakul et al., adjust for sex, household income, and paternal history of asthma

- Stark et al., adjusted for water damage or mold or mildew in year 1, African-American ethnicity, maternal Alternaria, lgE $>0.35 \mathrm{U} / \mathrm{mL}$

- Biagini et al., adjusted for mother's education, gender, cat and dog ownership, daycare attendance, breastfeeding and number of diaries returned 


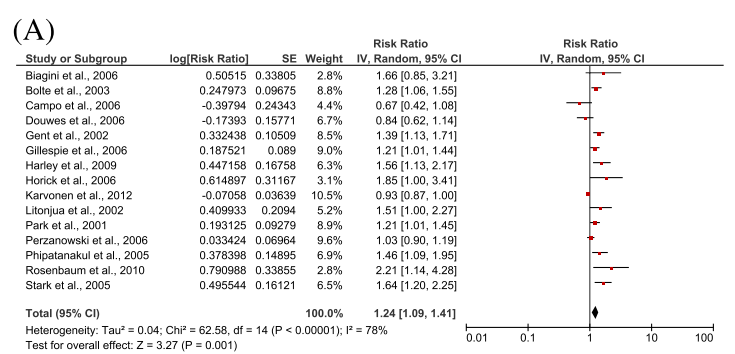

(B)



(C)

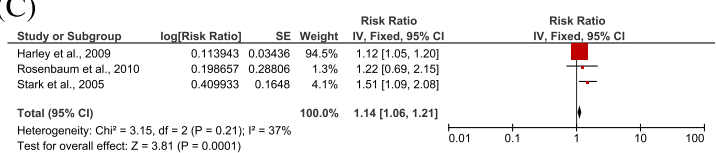

(D)

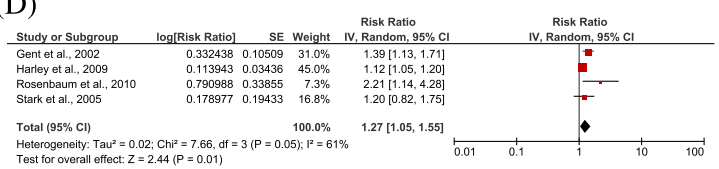

(E)

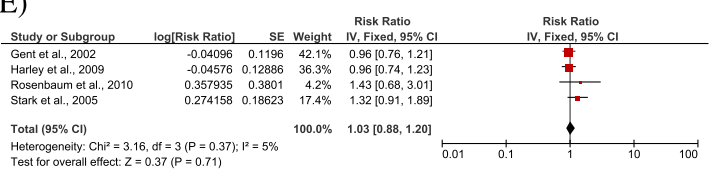

(F)

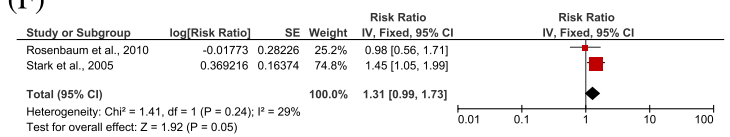

(G)

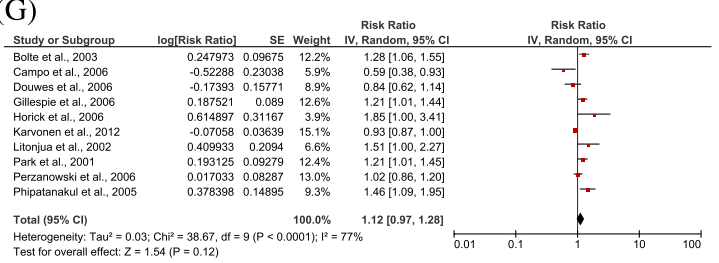

(H)

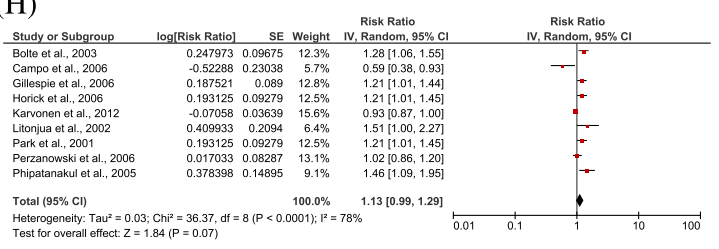

Fig. 2 Forest plot for the relationship between any IM exposure and Respiratory symptoms among $\mathrm{U}-5 \mathrm{C}$ with pooled effect estimates

(A); between TFC and Respiratory symptoms (B); between Aspergillus species and Respiratory symptoms (C); between Penicillium species and Respiratory symptoms (D); between Cladosporium species and Respiratory symptoms $(\mathbf{E})$; between Alternaria species and Respiratory symptoms (F); between Endotoxin and Respiratory symptoms $(\mathbf{G})$; between Endotoxin and Wheeze $(\mathbf{H})$ and the resulting inflamed mucosal tissue may provide a diminished barrier to respiratory infections [17]. Also, prolonged exposure to aerosolized fungal components mainly target the respiratory and nervous system causing specific pathological changes in the host characterized by inflammation and continuous activation of immune responses as a result of fungal exposures may contribute to inflammation-related diseases [52]. Our review considered exposure to visible molds only or in association with dampness, but excluded studies considering dampness alone. Indeed, mold and dampness exposures are often connected, leading to increased fungal growth and correlated microbial exposures, such as fungal spores, hyphae, fragments [53], microbial volatile organic compounds [54,55], mycotoxins [56], house dust mite allergens [57] and endotoxins [58, 59].

The definitions of respiratory outcomes among children $<6$ years of age are often poorly described and confusing, thereby making the diagnosis of the disease in preschool children difficult [60]. As a result, the European Respiratory Society task force proposed the use of terms such as "episodic (viral) wheeze" (among children with recurrent wheeze and who are well between episodes) and "multiple-trigger wheeze" (among children who wheeze both during and after discrete episodes) [61]. In fact, some other definitions have also been used to describe the different phenotypes of preschool wheezing disorders such as the presence of transient early wheezing in children $<3$ years, non-atopic wheezing in children aged 3-6 years, and IgE-mediated wheeze in older children [62]. More recent studies have suggested that these definitions may reflect disease severity and that they are likely to vary with time [63]. Specific factors responsible for the development of respiratory diseases in children $<6$ years has not been identified; however, interactions between the environment and genetic factors of each individual play a vital role [64]. These factors include infections, atopy, prematurity, exposure to tobacco smoke, exposure to elevated levels of air pollution or family history of asthma $[62,65,66]$. A recent meta-analysis reported an increased risk of lower respiratory tract infection among under-five children as a result of increased exposure to indoor microbes with emphasis on detailed microbial characterization using modern molecular techniques [67].

It was interesting to discover that none of the studies included in the present meta-analysis employed molecular-based techniques in the analysis of microbial agents. Although, studies have investigated the burden of indoor microbial exposures using sequencing-based assessment $[9,68-70]$ but very few demonstrated a link with disease epidemiology such as respiratory outcomes as revealed in the present study. This is probably due to the complexity 
Table 4 Combined effect estimate for the relationship between exposure to fungal genera and respiratory symptoms among U-5C

Model in subgroup analysis

\begin{tabular}{|c|c|c|}
\hline $\begin{array}{l}\text { Number } \\
\text { of } \\
\text { studies }\end{array}$ & $I^{2}(\%)$ & $\begin{array}{l}\text { Summary Effect Estimate } \\
\text { for pooled adjusted data } \\
{[95 \% \mathrm{Cl}]}\end{array}$ \\
\hline
\end{tabular}

Model 1: Two most reported fungal genera; Penicillium and Cladosporium species

$\begin{array}{lllr}(4) & 0 & 1.51[1.31,1.76] & <0.00001 \\ (3) & 0 & 1.66[1.34,2.06] & <0.00001 \\ (2) & 0 & 1.73[1.30,2.31] & 0.0002\end{array}$

Model 2: Three commonly reported fungal genera; Aspergillus, Penicillium, Cladosporium

Risk Ratio

Study or Subgroup

Bolte et al., 2003

Campo et al., 2006

Douwes et al., 2006

Gent et al., 2002

Gillespie et al., 2006

Harley et al., 2009

Horick et al., 2006

Karvonen et al., 2012

Litonjua et al., 2002

Park et al., 2001

Perzanowski et al., 2006

Phipatanakul et al., 2005

Rosenbaum et al., 2010

Total $(95 \% \mathrm{Cl})$

Heterogeneity: $\mathrm{Tau}^{2}=0.04 ; \mathrm{Chi}^{2}=55.21, \mathrm{df}=12(\mathrm{P}<0.00001) ; \mathrm{I}^{2}=78 \%$

Test for overall effect: $Z=2.60(P=0.009)$

Fig. 3 Forest plot for the relationship between any IM exposure and wheeze among U-5C with pooled effect estimates

$28[1.06,1.55]$
Risk Ratio

IV, Random, $95 \% \mathrm{CI}$

$0.67[0.42,1.08]$

$0.69[0.44,1.09]$

$1.39[1.13,1.71]$

$1.21[1.01,1.44]$

$1.56[1.13,2.17]$

$1.85[1.00,3.41]$

$0.93[0.87,1.00]$

$1.51[1.00,2.27]$

$1.21[1.01,1.45]$

$1.02[0.86,1.20]$

$1.46[1.09,1.95]$

$2.21[1.14,4.28]$

$1.20[1.05,1.38]$




of the microbial exposure and the lack of clear understanding of the mechanism involved in the association between indoor microbial agents and disease outcomes.

Recent studies have emphasized the protective effect of exposure to endotoxins [25, 26, 71-73] against respiratory allergies and allergic asthma. Our findings corroborate these reports but contradicts some findings among older children [74-76] and adults [77-79]. A previous study reported that exposure to endotoxin has been associated with reduced risk of childhood atopy but an increased risk of wheeze [80]. A comprehensive meta-analysis confirmed this contradiction with respect to endotoxin exposure [73]. Among pre-school children, in whom asthma is more strongly associated with atopy, endotoxin exposure resulted in reduced risk, whereas among infants and toddlers with virus-triggered wheeze, endotoxin increased the risk [73]. Similar findings were reported from the survey carried out by the National Health and Nutrition Examination Survey study enrolling more than 6,000 subjects across the United States. They found that endotoxin was a risk for wheeze but not asthma [59]. Less is known about other bacterial and fungal exposures in indoor urban homes. In the Boston cohort increased levels of muramic acid as a marker for gram-positive bacteria were inversely associated with current asthma but not with allergic sensitization [80]. However, the mechanisms are still not fully understood. Possible explanation indicate that endotoxin is a potent inducer of interleukin-12 and interferon gamma, which downregulate the production of T-lymphocyte helper 2 (Th2) cells involved in the development of allergic diseases [81]. Besides, the potential of T-lymphocyte helper 1 (Th1) inducers like endotoxin and other microbial exposures to mitigate allergy and asthma is consistent with clinical studies. Overall, evidence of the mechanism of association between exposure to indoor microbes and respiratory outcomes is limited. Nevertheless, further longitudinal studies of the effect of early-life exposure to endotoxins on subsequent child health will be needed to understand this mechanism more fully.

In addition, studies included in the meta-analyses have used proxy measures for estimating respiratory health outcome, such as outcome obtained from parental or other caregiver interviews, questionnaires, and medical records. None of the studies quantified indoor microbial contamination to the species level using molecular techniques, which restricted analyses to the fungal genera and potentially underestimate exposures. Also, the differences in the RRs across the included studies could have also contributed to the high heterogeneity. Regardless of these limitations, this study has provided sufficient evidence required in designing future longitudinal studies to further investigate and explain the mechanism involved in the exposure-response relationship between indoor microbial exposure and respiratory symptoms among children under 5.

\section{Conclusions}

Indoor microbial aerosol exposures increase the risk of respiratory symptoms such as wheeze and allergic rhinitis but protect against asthma in children under 5 . More research regarding these relationships is required using modern analytical approaches such as molecularbased sequencing techniques to better inform/advise parents, form guidelines to reduce exposure to microbial agents within the indoor environment and provide useful intervention strategies for managing the impact of exposure to microbial agents in association with respiratory symptoms among children under the age of 5 years.

\section{Abbreviations}

Cl: Confidence interval; NOS: Newcastle-Ottawa Scale; OR: Odds ratio; RR: Relative risk; SE: Standard error; EEs: Summary effect estimates; $P$ : $P$-Value; Th1:T-lymphocyte helper 1;Th2: T-lymphocyte helper 2; CD14: Cluster of differentiation 14; PRISMA: Preferred Reporting Item for Systematic Review and Meta-analyses.

\section{Supplementary Information}

The online version contains supplementary material available at https://doi. org/10.1186/s12940-021-00759-2.

Additional file 1: Table S1. Quality Assessment of studies included in the meta-analysis using the Newcastle-Ottawa Scaling. Table S2. Leave-oneout sensitivity Analysis of pooled effect estimates of studies included in the meta-analysis. Figure S1. Funnel plots with pseudo-95\% confidence limit for any IM exposure and wheeze among U-5C (A); TFC and wheeze (B); Aspergillus spp. and wheeze (C); Penicillium spp. and wheeze (D); Cladosporium spp and wheeze (E); Endotoxin and wheeze (F). Figure S2. Funnel plots with pseudo-95\% confidence limit for any IM exposure and allergic rhinitis among $U-5 C(A)$; visible mold and allergic rhinitis (B); Endotoxin and allergic rhinitis (C). Figure S3. Funnel plots with pseudo-95\% confidence limit for any IM exposure/endotoxin and asthma among U-5C.

\section{Acknowledgements}

We acknowledged support of the European Respiratory Society - ERS Shortterm Research Fellowship April 2020 (STRF April 2020)- STRTF202004-00799.

\section{Authors' contributions}

AGF and NJ performed the literature search, evaluated the titles and abstracts of each articles independently and the differences on which article to include were clarified by recourse to RNN. AGF and NJ independently performed the data extraction. AGF developed the first manuscript draft, carried out the statistical analyses, and quality assessment on the included studies. RNN and LAMS supervised the whole process and reviewed the manuscript. All authors contributed to the interpretation of the data, read and approved the final manuscript

\section{Funding}

None.

Availability of data and materials

All data generated or analysed during this study are included in this published article and its additional files. 


\section{Declarations}

Ethics approval and consent to participate

Not applicable.

\section{Consent for publication}

Not applicable.

\section{Competing interests}

The authors have no competing interest to declare.

\section{Author details}

${ }^{1}$ Discipline of Occupational and Environmental Health, School of Nursing and Public Health, University of KwaZulu-Natal, Durban, South Africa. 2Department of Medicine, University of Ibadan, Ibadan 200284, Nigeria. ${ }^{3}$ Institute for Risk Assessment Sciences, Environmental Epidemiology Division (IRAS-EEPI), Utrecht University, Utrecht, The Netherlands.

\section{Received: 16 September 2020 Accepted: 18 June 2021}

Published online: 01 July 2021

\section{References}

1. National Academies of Sciences EaMN. Microbiomes of the built environment: a research agenda for indoor microbiology, human health and buildings. Washington, DC: The National Academies Press; 2017.

2. Nevalainen A, Seuri M. Of microbes and men. Indoor Air. 2005;15(Suppl 9):58-64.

3. Brasche S, Bischof W. Daily time spent indoors in German homes - Baseline data for the assessment of indoor exposure of German occupants. Int J Hyg Environ Health. 2005;208(4):247-53.

4. Nazaroff WW. Embracing microbes in exposure science. J Expo Sci Environ Epidemiol. 2019;29(1):1-10.

5. Dunn RR, Fierer N, Henley JB, Leff JW, Menninger HL. Home life: factors structuring the bacterial diversity found within and between homes. PLoS One. 2013;8(5):e64133.

6. Sordillo JE, Alwis UK, Hoffman E, Gold DR, Milton DK. Home characteristics as predictors of bacterial and fungal microbial biomarkers in house dust. Environ Health Perspect. 2011;119(2):189-95.

7. Shelton BG, Kirkland KH, Flanders WD, Morris GK. Profiles of airborne fungi in buildings and outdoor environments in the United States. Appl Environ Microbiol. 2002;68(4):1743-53.

8. Fujimura KE, Johnson CC, Ownby DR, Cox MJ, Brodie EL, Havstad SL, et al. Man's best friend? The effect of pet ownership on house dust microbial communities. J Allergy Clin Immunol. 2010;126(2):410-2, 2.e1-3.

9. Kettleson EM, Adhikari A, Vesper S, Coombs K, Indugula R, Reponen T. Key determinants of the fungal and bacterial microbiomes in homes. Environ Res. 2015:138:130-5.

10. Gliniewicz A, Czajka E, Laudy AE, Kochman M, Grzegorzak K, Sawicka B, et al. German cockroaches (Blattella Germanica L.) as a potential source of pathogens causing nosocomial infections. Indoor Built Environ. 2003;12:55-60.

11. Adams RI, Miletto M, Lindow SE, Taylor JW, Bruns TD. Airborne bacterial communities in residences: similarities and differences with fungi. PLoS One. 2014;9(3):e91283.

12. Meadow JF, Altrichter AE, Kembel SW, Kline J, Mhuireach G, Moriyama $M$, et al. Indoor airborne bacterial communities are influenced by ventilation, occupancy, and outdoor air source. Indoor Air. 2014;24(1):41-8.

13. Emerson J, Keady P, Brewer T, Clements N, Morgan E, Awerbuch J, et al. Impacts of flood damage on airborne bacteria and fungi in homes after the 2013 Colorado Front Range flood. Environ Sci Technol. 2015;49(5):2675-84.

14. Norback D, Cai GH. Dampness, indoor mould, fungal DNA and respiratory health - molecular methods in indoor epidemiology. Clin Exp Allergy. 2015;45(5):840-3.

15. Sharpe RA, Bearman N, Thornton CR, Husk K, Osborne NJ. Indoor fungal diversity and asthma: a meta-analysis and systematic review of risk factors. J Allergy Clin Immunol. 2015;135(1):110-22.
16. Jaakkola MS, Quansah R, Hugg TT, Heikkinen SA, Jaakkola JJ. Association of indoor dampness and molds with rhinitis risk: a systematic review and meta-analysis. J Allergy Clin Immunol. 2013;132(5):1099-110.e18.

17. Fisk WJ, Eliseeva EA, Mendell MJ. Association of residential dampness and mold with respiratory tract infections and bronchitis: a meta-analysis. Environ Health. 2010;9:72-82.

18. Kirjavainen PV, Karvonen AM, Adams RI, Täubel M, Roponen M, Tuoresmäki $P$, et al. Farm-like indoor microbiota in non-farm homes protects children from asthma development. Nat Med. 2019;25(7):1089-95.

19. O'Connor GT, Lynch SV, Bloomberg GR, Kattan M, Wood RA, Gergen PJ, et al. Early-life home environment and risk of asthma among inner-city children. J Allergy Clin Immunol. 2018;141(4):1468-75.

20. Ege MJ, Mayer M, Normand AC, Genuneit J, Cookson WO, Braun-Fahrlander $C$, et al. Exposure to environmental microorganisms and childhood asthma. N Engl J Med. 2011;364(8):701-9.

21. Jacobs J, Borras-Santos A, Krop E, Taubel M, Leppanen H, HaverinenShaughnessy $U$, et al. Dampness, bacterial and fungal components in dust in primary schools and respiratory health in schoolchildren across Europe. Occup Environ Med. 2014;71(10):704-12.

22. Simoni M, Cai GH, Norback D, Annesi-Maesano I, Lavaud F, Sigsgaard T, et al. Total viable molds and fungal DNA in classrooms and association with respiratory health and pulmonary function of European schoolchildren. Pediatr Allergy Immunol. 2011;22(8):843-52.

23. Stark PC, Celedon JC, Chew GL, Ryan LM, Burge HA, Muilenberg ML, et al. Fungal levels in the home and allergic rhinitis by 5 years of age. Environ Health Perspect. 2005;113(10):1405-9.

24. Reponen T, Lockey J, Bernstein DI, Vesper SJ, Levin L, Khurana Hershey GK, et al. Infant origins of childhood asthma associated with specific molds. J Allergy Clin Immunol. 2012;130(3):639-44.e5.

25. Carlsten C, Ferguson A, Dimich-Ward H, Chan H, DyBuncio A, Rousseau $\mathrm{R}$, et al. Association between endotoxin and mite allergen exposure with asthma and specific sensitization at age 7 in high-risk children. Pediatr Allergy Immunol. 2011;22(3):320-6.

26. Tischer C, Gehring U, Chen CM, Kerkhof M, Koppelman G, Sausenthaler $\mathrm{S}$, et al. Respiratory health in children, and indoor exposure to $(1,3)$ - -D-glucan, EPS mould components and endotoxin. Eur Respir J. 2011:37(5):1050-9.

27. Fakunle GA, Olusola B, Jafta N, Faneye A, Heederik D, Smit AML, et al. Home Assessment of Indoor Microbiome (HAIM) in relation to lower respiratory tract infections among under-five children in Ibadan, Nigeria: the study protocol. Int J Environ Res Public Health. 2020;17(6):1857

28. Zeldin DC, Eggleston P, Chapman M, Piedimonte G, Renz H, Peden D. How exposures to biologics influence the induction and incidence of asthma. Environ Health Perspect. 2006;114(4):620-6.

29. Martinez FD, Wright AL, Taussig LM, Holberg CJ, Halonen M, Morgan WJ. Asthma and wheezing in the first six years of life. The Group Health Medical Associates. N Engl J Med. 1995;332(3):133-8.

30. Higgins JP, Thompson SG, Deeks JJ, Altman DG. Measuring inconsistency in meta-analyses. BMJ. 2003:327(7414):557-60.

31. Higgins JPT, Green S, editors. Cochrane handbook for systematic reviews of interventions. The Cochrane Collaboration; 2011. Available from www. cochrane-handbook.org.

32. Wells GA, Shea B, O'Connell D, Peterson J, Welch V, Losos M, et al. The Newcastle-Ottawa Scale (NOS) for assessing the quality of nonrandomised studies in meta-analyses. Canada: Ottawa Hospital Research Institute; 2014. Available from: http://www.ohri.ca/programs/clinical_ epidemiology/oxford.asp.

33. DerSimonian R, Laird N. Meta-analysis in clinical trials. Control Clin Trials. 1986;7(3):177-88

34. The Cochrane Collaboration. Review Manager (RevMan) [Computer program]. Version 5.3. ed The Nordic Cochrane Centre. Copenhagen: The Cochrane Collaboration; 2014.

35. Gent JF, Ren P, Belanger K, Triche E, Bracken MB, Holford TR, et al. Levels of household mold associated with respiratory symptoms in the first year of life in a cohort at risk for asthma. Environ Health Perspect. 2002;110(12):A781-6. 
36. Rosenbaum PF, Crawford JA, Anagnost SE, Wang CJ, Hunt A, Anbar RD, et al. Indoor airborne fungi and wheeze in the first year of life among a cohort of infants at risk for asthma. J Expo Sci Environ Epidemiol. 2010;20(6):503-15.

37. Horick N, Weller E, Milton DK, Gold DR, Li R, Spiegelman D. Home endotoxin exposure and wheeze in infants: correction for bias due to exposure measurement error. Environ Health Perspect. 2006;114(1):135-40.

38. Park JH, Gold DR, Spiegelman DL, Burge HA, Milton DK. House dust endotoxin and wheeze in the first year of life. Am J Respir Crit Care Med. 2001;163(2):322-8.

39. Harley KG, Macher JM, Lipsett M, Duramad P, Holland NT, Prager SS, et al. Fungi and pollen exposure in the first months of life and risk of early childhood wheezing. Thorax. 2009;64(4):353-8.

40. Litonjua AA, Milton DK, Celedon JC, Ryan L, Weiss ST, Gold DR. A longitudinal analysis of wheezing in young children: the independent effects of early life exposure to house dust endotoxin, allergens, and pets. J Allergy Clin Immunol. 2002;110(5):736-42.

41. Campo P, Kalra HK, Levin L, Reponen T, Olds R, Lummus ZL, et al. Influence of dog ownership and high endotoxin on wheezing and atopy during infancy. J Allergy Clin Immunol. 2006;118(6):1271-8.

42. Gillespie J, Wickens K, Siebers R, Howden-Chapman P, Town I, Epton $M$, et al. Endotoxin exposure, wheezing, and rash in infancy in a New Zealand birth cohort. J Allergy Clin Immunol. 2006;118(6):1265-70.

43. Perzanowski MS, Miller RL, Thorne PS, Barr RG, Divjan A, Sheares $B J$, et al. Endotoxin in inner-city homes: associations with wheeze and eczema in early childhood. J Allergy Clin Immunol. 2006;117(5):1082-9.

44. Karvonen AM, Hyvarinen A, Gehring U, Korppi M, Doekes G, Riedler J, et al. Exposure to microbial agents in house dust and wheezing, atopic dermatitis and atopic sensitization in early childhood: a birth cohort study in rural areas. Clin Exp Allergy. 2012;42(8):1246-56.

45. Biagini JM, LeMasters GK, Ryan PH, Levin L, Reponen T, Bernstein DI, et al. Environmental risk factors of rhinitis in early infancy. Pediatr Allergy Immunol. 2006;17(4):278-84.

46. Bolte G, Bischof W, Borte M, Lehmann I, Wichmann HE, Heinrich J. Early endotoxin exposure and atopy development in infants: results of a birth cohort study. Clin Exp Allergy. 2003;33:770-6.

47. Douwes J, van Strien R, Doekes G, Smit J, Kerkhof M, Gerritsen J, et al. Does early indoor microbial exposure reduce the risk of asthma? The prevention and incidence of asthma and mite allergy birth cohort study. J Allergy Clin Immunol. 2006;117(5):1067-73.

48. Phipatanakul W, Celedon JC, Sredl DL, Weiss ST, Gold DR. Mouse exposure and wheeze in the first year of life. Ann Allergy Asthma Immunol. 2005;94(5):593-9

49. Stark PC, Burge HA, Ryan LM, Milton DK, Gold DR. Fungal levels in the home and lower respiratory tract illnesses in the first year of life. Am J Respir Crit Care Med. 2003;168(2):232-7.

50. Matheson MC, Abramson MJ, Dharmage SC, Forbes AB, Raven JM, Thien FC, et al. Changes in indoor allergen and fungal levels predict changes in asthma activity among young adults. Clin Exp Allergy. 2005;35(7):907-13.

51. Antova T, Pattenden S, Brunekreef B, Heinrich J, Rudnai P, Forastiere F, et al. Exposure to indoor mould and children's respiratory health in the PATY study. J Epidemiol Community Health. 2008;62(8):708-14.

52. Desoubeaux G, Cray C. Animal models of aspergillosis. Comp Med. 2018;68(2):109-23.

53. Reponen T, Seo SC, Grimsley F, Lee T, Crawford C, Grinshpun SA. Fungal fragments in moldy houses: a field study in homes in New Orleans and Southern Ohio. Atmos Environ. 2007:41(37):8140-9.

54. Korpi A, Jarnberg J, Pasanen AL. Microbial volatile organic compounds. Crit Rev Toxicol. 2009;39(2):139-93.

55. Moularat S, Robine E, Ramalho O, Oturan MA. Detection of fungal development in a closed environment through the identification of specific VOC: demonstration of a specific VOC fingerprint for fungal development. Sci Total Environ. 2008;407(1):139-46.

56. Wong J, Magun BE, Wood LJ. Lung inflammation caused by inhaled toxicants: a review. Int J Chron Obstruct Pulmon Dis. 2016;11:1391-401.
57. Zock JP, Heinrich J, Jarvis D, Verlato G, Norback D, Plana E, et al. Distribution and determinants of house dust mite allergens in Europe: the European Community Respiratory Health Survey II. J Allergy Clin Immunol. 2006;118(3):682-90.

58. Caillaud D, Evrard B, Laurichesse H, Souweine B. Role of indoor endotoxins in asthma symptoms. Rev Mal Respir. 2009;26(8):893-9.

59. Thorne PS, Mendy A, Metwali N, Salo P, Co C, Jaramillo R, et al. Endotoxin exposure: predictors and prevalence of associated asthma outcomes in the United States. Am J Respir Crit Care Med. 2015;192(11):1287-97.

60. Vogelberg C. Preschool children with persistent asthmatic symptoms. Ther Clin Risk Manag. 2019;15:451-60.

61. Brand PL, Baraldi E, Bisgaard H, Boner AL, Castro-Rodriguez JA, Custovic $A$, et al. Definition, assessment and treatment of wheezing disorders in preschool children: an evidence-based approach. Eur Respir J. 2008;32(4):1096-110.

62. Martinez FD. Development of wheezing disorders and asthma in preschool children. Pediatrics. 2002;109(2):362-7.

63. Schultz A, Devadason SG, Savenije OE, Sly PD, Le Souëf PN, Brand PL. The transient value of classifying preschool wheeze into episodic viral wheeze and multiple trigger wheeze. Acta Paediatr. 2010;99(1):56-60.

64. van Aalderen WM. Childhood asthma: diagnosis and treatment. Scientifica. 2012;2012:674204

65. Beasley R, Semprini A, Mitchell EA. Risk factors for asthma: is prevention possible? Lancet. 2015;386(9998):1075-85.

66. Kravitz-Wirtz N, Teixeira S, Hajat A, Woo B, Crowder K, Takeuchi D. Early-life air pollution exposure, neighborhood poverty, and childhood asthma in the United States, 1990-2014. Int J Environ Res Public Health. 2018;15(6):1114

67. Fakunle AG, Jafta N, Okekunle AP, Naidoo RN. Indoor microbiome and risk of lower respiratory tract infections among children under-five years: a meta-analysis. Indoor Air. 2020;30(5):795-804.

68. Prussin AJ 2nd, Garcia EB, Marr LC. Total virus and bacteria concentrations in indoor and outdoor air. Environ Sci Technol Lett. 2015:2(4):84-8.

69. Prussin AJ, Torres PJ, Shimashita J, Head SR, Bibby KJ, Kelley ST, et al. Seasonal dynamics of DNA and RNA viral bioaerosol communities in a daycare center. Microbiome. 2019;7(1):53.

70. Blachere FM, Lindsley WG, Pearce TA, Anderson SE, Fisher M, Khakoo R, et al. Measurement of airborne influenza virus in a hospital emergency department. Clin Infect Dis. 2009;48(4):438-40.

71. Sordillo J, Hoffman PE, Celedon J, Litonjua A, Milton D, Gold D. Multiple microbial exposures in the home may protect against asthma or allergy in childhood. Clin Exp Allergy. 2010;40:902-10.

72. Ober C, Vercelli D. Gene-environment interactions in human disease: nuisance or opportunity? Trends Genet. 2011;27(3):107-15.

73. Mendy A, Gasana J, Vieira ER, Forno E, Patel J, Kadam P, et al. Endotoxin exposure and childhood wheeze and asthma: a meta-analysis of observational studies. J Asthma. 2011:48(7):685-93.

74. Gehring U, Strikwold M, Schram-Bijkerk D, Weinmayr G, Genuneit J, Nagel G, et al. Asthma and allergic symptoms in relation to house dust endotoxin: phase two of the International Study on Asthma and Allergies in Childhood (ISAAC II). Clin Exp Allergy. 2008:38(12):1911-20.

75. Lawson JA, Dosman JA, Rennie DC, Beach J, Newman SC, Senthilselvan A. Relationship between indoor environment and asthma and wheeze severity among rural children and adolescents. J Agromedicine. 2009;14(2):277-85.

76. Lai PS, Sheehan WJ, Gaffin JM, Petty CR, Coull BA, Gold DR, et al. School endotoxin exposure and asthma morbidity in inner-city children. Chest. 2015;148(5):1251-8.

77. Thorne PS, Kulhánková K, Yin M, Cohn R, Arbes SJ Jr, Zeldin DC. Endotoxin exposure is a risk factor for asthma: the national survey of endotoxin in United States housing. Am J Respir Crit Care Med. 2005;172(11):1371-7.

78. Carnes MU, Hoppin JA, Metwali N, Wyss AB, Hankinson JL, $\mathrm{O}^{\prime} \mathrm{Connell} \mathrm{EL}$, et al. House dust endotoxin levels are associated with adult asthma in a U.S. farming population. Ann Am Thorac Soc. 2017:14(3):324-31. 
79. Kanchongkittiphon W, Mendell MJ, Gaffin JM, Wang G, Phipatanakul W. Indoor environmental exposures and exacerbation of asthma: an update to the 2000 review by the Institute of Medicine. Environ Health Perspect. 2015;123(1):6-20

80. Celedón JC, Milton DK, Ramsey CD, Litonjua AA, Ryan L, Platts-Mills $T A$, et al. Exposure to dust mite allergen and endotoxin in early life and asthma and atopy in childhood. J Allergy Clin Immunol. 2007:120(1):144-9

81. Gereda JE, Leung DY, Thatayatikom A, Streib JE, Price MR, Klinnert $M D$, et al. Relation between house-dust endotoxin exposure, type 1 T-cell development, and allergen sensitisation in infants at high risk of asthma. Lancet. 2000;355(9216):1680-3.

\section{Publisher's Note}

Springer Nature remains neutral with regard to jurisdictional claims in published maps and institutional affiliations.

- fast, convenient online submission

- thorough peer review by experienced researchers in your field

- rapid publication on acceptance

- support for research data, including large and complex data types

- gold Open Access which fosters wider collaboration and increased citations

- maximum visibility for your research: over $100 \mathrm{M}$ website views per year

At BMC, research is always in progress.

Learn more biomedcentral.com/submissions 